\title{
BURNT STONE AT WEST HEATH, HAMPSTEAD
}

Myfanwy Stewart Institute of Archaeology

\section{Introduction}

British mesolithic sites, often on acid sands, tend to yield little organic material other than charcoal. Flint assemblages form the greatest part of the archaeological evidence. Quantities of burnt stone are usually present. They may be a source of information on past activities and so provide important supporting data for the knapped flint. Experiments were carried out to ascertain if the red and white stones, recovered at West Heath, had been bumt. Recording seemed justified and this led to an attempt to trace the extent of the ancient fires.

The site of West Heath is in the London Borough of Camden. It is located on the west side of Hampstead Heath beside the Leg of Mutton pond just outside Golders Hill Park (TQ 256686. 76). The area, once owned by the Greater London Council, is now administered by the London Residuary Body (Fig. 1).

\section{Geology}

Hampstead Heath is situated on a southern outlier of the Claygate Beds capped by Bagshot Sands (Bromehead, 1925, 28). The Claygate Beds are an intermediary stage between the London Clay, which they adjoin, and the Bagshot Sands. Numerous fresh water springs rise from the junction of the sands and clays and evidence of several small stream systems can be seen in the woodland near the site today. The Leg of Mutton pond was made by the damming of a chalybeate brook rising some $300 \mathrm{~m}$ to the South East. Thus the encampment would have been established in the favourable environment of an ecotone, here resulting from the the juxtaposition of the London Clay and the Bagshot Sands, and would have had a ready supply of fresh water.

\section{The soil}

Much of the site shows the development of an undulating podzol of varying depth. When present beneath the upper turf, the podzol consists of a bleached clay depleted eluvial $\mathrm{E}_{\mathrm{a}}$ horizon overlying a $\mathrm{B}_{\mathrm{h}} / \mathrm{C}$ deposit containing the translocated clay. The lowest horizon, C, is a yellow sandy clay. When the podzol is not apparent, pinky-brown sandy loam is found between the upper turf and the lower yellow clay. The average $\mathrm{pH}$ is 3.7 .

\section{Phase 1 Excavations 1976-1981.}

In 1976 the G.L.C. gave the Hendon and District Archaeological Society permission to excavate an area beside the Leg of Mutton pond. The site, well used by walkers and with an unstable bluff to the West, was under threat of erosion. Work continued on a part-time basis up to 1981 under the direction of Dr. Desmond Collins and Daphne Home-Lorimer.

The site was excavated by $5 \mathrm{~cm}$ spits in squares of $2 \mathrm{~m}$. Each spit was charted and, at first, both struck flint and burnt stone were recorded three dimensionally. Spoil was double sieved. After two seasons the burnt material was 

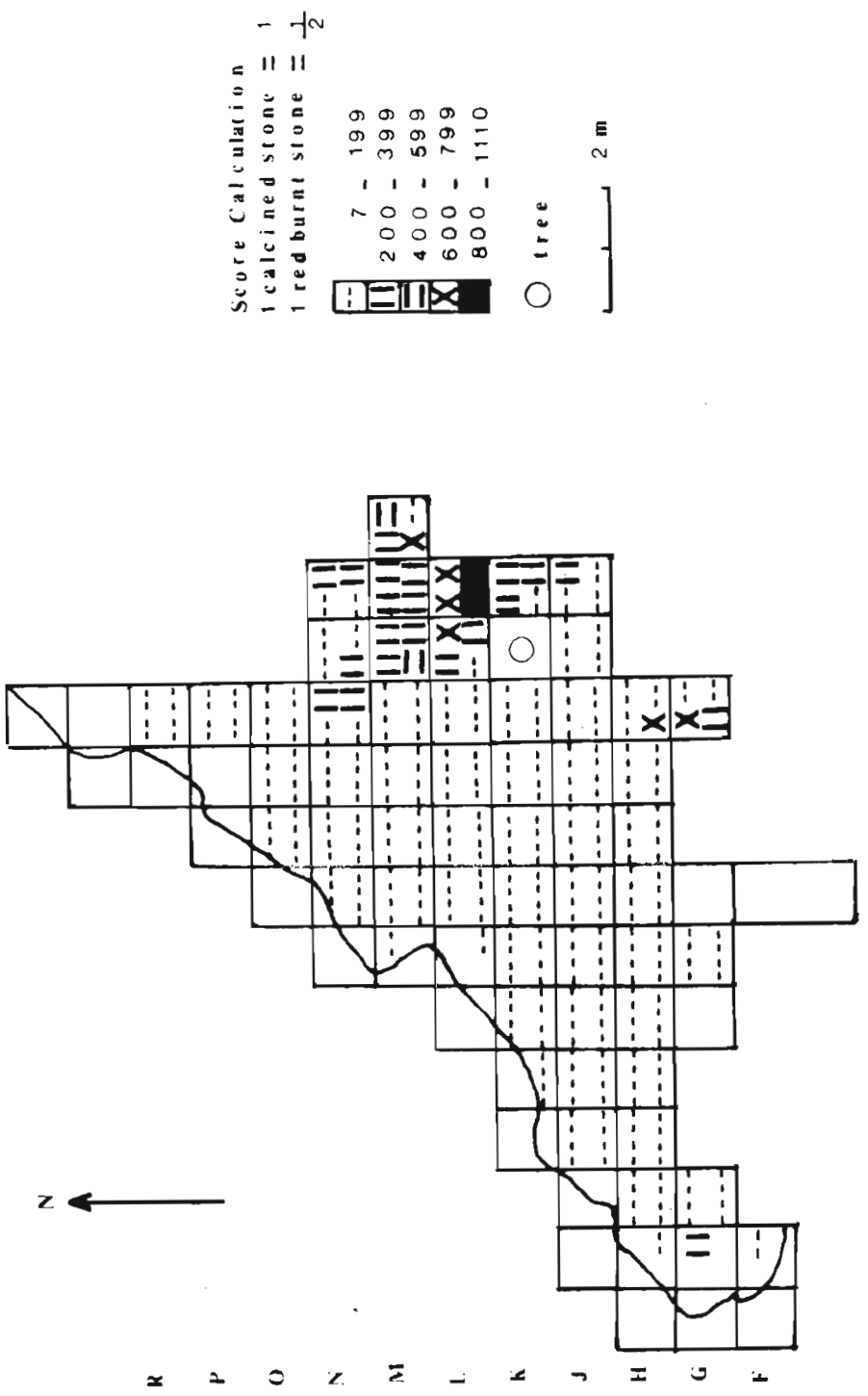
retained in 4 bags, representing the quarters of each trench, and which were renewed at each spit.

\section{Phase 2 Excavations 1984-1986}

From 1984-1986 the site was excavated under the direction of Margarel Maher. Trenches of $1 \mathrm{~m}$. square were worked in $2 \mathrm{~cm}$ spits and the bumt stone was bagged in squares of $50 \mathrm{~cm}$ corresponding with the quarters of the trench. Other finds were recorded three dimensionally, charts were renewed every $2 \mathrm{~cm}$ and stones over 3 $\mathrm{cm}$. were drawn on the plans. All spoil was dry sieved twice and then wet sieved. All changing soil patterns were recorded with particular reference to the onset and development of the podzol formation.

\section{The Material}

The low pH factor prevents the survival of bone. In the almost total absence of organic remains, bumt stone was the only recoverable material available in quantity for providing possible behavioural evidence to support the spatial analysis of the 100,000 or more struck flakes that have now been found.

In 1976 the stones, assumed to be burnt fragments of the yellow chert occurring naturally on the site, were easily visible in the light coloured soil, much of which was podzolised. They consisted of white and pink "pot boilers" together with uncalcined stones in various shades of red. Recording began when it became apparent that they were not merely a surface scatter.

However it was not certain if all the stones were burnt. Some of the red ones especially seemed suspect. None had been arranged as a recognisable hearth. It became evident that the great deal of time spent in the three dimensional recording had to be justified. In any event the quarter bag system was adopted after two seasons, as mentioned above, because it was felt that it provided sufficient accuracy.

The Fire Research Station at Boreham Wood, Herts. was consulted firstly because it was uncertain if fire would redden the stone which predominated at West Heath. Secondly they were asked if a wood fire, presumably with no induced draught, would result in temperatures sufficiently high to calcine stone. Th Research Station stated that little work had been done in the field but that an H.M.S.O publication The Investigation of Building Fires (1950) dealt with aggregates containing stone and flint. This publication confirmed that the development of red "corresponds with the dehydration of iron compounds and that its presence is a reliable indication that the sample has been heated to a temperature of at least 250-300 $\mathrm{C}^{\prime \prime}$ (Bessey, 1950,7).

The white or pale pink crazed stone is the result of higher temperatures. Tests by the Building Research Station stated that some shattering of the flint occurred around $500^{\circ} \mathrm{C}$ and that it became lighter in colour. This was partly due to water loss and partly to the expansion of quartz grains and the subsequent inversion of the $\partial$ and $B$ forms (Bessey, 1950). Weymouth and Williams $(1951,587)$ would put the temperature lower. They state that "the whitening of flint which accompanies calcination becomes significant at $400^{\circ} \mathrm{C}$ and is especially obvious in the range 500$600^{\circ} \mathrm{C}^{\prime \prime}$. Shattering was also confirmed. Inizan, Roche and Tixier $(1976-77,9)$ tested six types of stone and found that five changed colour and reddened at $350^{\circ} \mathrm{C}$ whereas one, a type of quartzite, altered at $280^{\circ} \mathrm{C}$. Melcher and Zimmerman (1977, 1361) warn that there may be little correlation between heated stone and its visual appearance. Red colour can be a natural phenomenon and a red artefact that had been 
submitted to thermoluminescence tests proved not to be burnt at all. Price et.al. $(1982,471)$ confirmed that "the degree of alteration clearly depends upon the type of flint involved". They believe there is a rough correlation between the size of stones and heat-induced colour change; the smaller the piece, the swifter the alteration in colour. Their experiments on the flint from Havelte, a mesolithic site in the Northern Netherlands, produced colour change at $250^{\circ} \mathrm{C}$.

The Fire Research Station stated that a wood fire with no induced draught would be quite capable of producing temperatures high enough to calcine flint. Glowing embers would be between $600^{\circ} \mathrm{C}$ and $700^{\circ} \mathrm{C}$, yellow embers hotter still and the temperature of flames likely to be $1200^{\circ} \mathrm{C}$. However, Price et. al. $(1982,473)$ quoting Manderville (1973) put the maximum temperatures of a wood fire at $800^{\circ} \mathrm{C}$.

Crabtree and Butler $(1964,2)$ experimented to assess how much heat was needed to make flint easier to knap. They found that, as silica materials vary, the temperatures and exposure time required to bring about change, differ too. Consequently they make the important point that materials used in experiments must resemble those of the archaeological specimens as closely as possible.

\section{The experiments with the West Heath Material}

The most common type of stone on the surface at West Heath is yellowish brown (10YR 5/6) and chert-like with a dark grey cortex (10YR 4/1). It was rarely used for knapping and, apart from a few flakes, no tools made with this stone have ever been found on the site.

A domestic oven, capable of producing temperatures of $285^{\circ} \mathrm{C}$ was used in tests for heat-induced colour change at the lowest scale. Pieces of the yellow stone together with examples of the harder, grey flint surface finds from the site and similar to that used by the mesolithic knappers, were heated from two to twelve hours.

The yellow stone, because of its iron content, reddened to $10 \mathrm{R} 5 / 6$ within four hours and after seven hours had deepened to $10 \mathrm{R} 3 / 6$, a dark red. A longer period of heating did not change the colour and it closely resembled the red stone found throughout the excavation. Price et. al. (Ibid, 471) confirmed that "only a certain degree of colour change will occur at low temperatures regardless of the length of heating".

The hard grey flint was almost unaffected except for a slight pinkish tone and a little clouding on some of the broken surfaces. No lustre was observed although the red stone had developed a greasy shine. Price et. al. found that most of the Havelte stone became lustrous around $300^{\circ} \mathrm{C}$ (Ibid, 471). Thus the evidence of fire where the yellow stone was involved would be easy to detect but the lightly burnt struck flint might well go unrecognised to the naked eye.

Tests above $285^{\circ} \mathrm{C}$ were done by Johnson Matthey Chemicals in their small test kilns in an oxygenated atmosphere. After 4 hours at $600^{\circ} \mathrm{C}$ all samples became faded and chalk-like and again resembled closely stones recovered from the site. The specimens were friable and colours ranged from light red $(2.5 \mathrm{YR} 6 / 6)$ to pale pink (5YR 7/3). After a further 17 hours all the stones were shattered and white.

The results of these tests apertain to West Heath only and were carried out to enquire into a problem that arose during excavation. As has been seen, no hard and fast rule exists that proves stone of a particular colour has been subjected to a particular amount of heat. All that can be said is that the experiments confirmed that 
the red stones at West Heath had been burnt, the calcined stones were the result of exposure to high temperatures and that both types were worth the effort of recovery.

It appears that the white crazed flint could be the result of fires "kept in" and left burning for several hours, re-lit fires or re-used stone. Concentrations might suggest the centres of fires whereas quantities of red stones might indicate the cooler perimeters.

\section{Processing Phase 1}

Excavated stones were colour matched with examples from the experiment. They were counted and a record kept of all stones over $3 \mathrm{~cm}$. A distribution map was drawn up for each spit with each red stone given a score of $1 / 2$, and each calcined, highly burnt stone a value of 1 . Specimens that were neither flint nor chert were extracted and form another avenue of research.

\section{Processing Phase 2}

The stones were processed as before but, because of the more refined excavation methods, fluctuation in the amount of burnt stone in each $50 \mathrm{~cm}$. square could be seen throughout the excavation at $2 \mathrm{~cm}$. intervals. Plans were drawn up showing the changes in the pattems of leaching, indicated by the white podzol, and the appropriate burnt stone distribution superimposed.

A grant from the London University Central Research Fund in 1988 enabled the thin-sectioning of a selection of non-flint geological specimens from both phases of the excavation to be carried out. Results of the thin-sectioning will be published when available.

\section{Results of Phase 1}

The quantity of burnt stone increases in an easterly direction across the site, culminating in the area XIVL. Figure 2 shows the total amount from all levels. During the excavation of the lowest levels of XIVL, when sandy clay had been reached, an easily visible patch of podzol, filled with highly burnt stone was seen to penetrate the clay. The feature proved to be a dumbell-shaped cavity, probably the remains of two separate pits that may have been used for cooking.

The increase of burnt material coincides with the amount of recorded struck flint throughout the site. A probable knapping area lies to the N.E. of the XIVL burnt stone concentration. The fire would have provided light as well as heat and may have been in the focal part of the group.

In the South of the site trenches XIIH and XIIG also feature a pit filled with podzol (Fig.3). Little evidence was found in the upper levels but large quantities of highly calcined stones were recorded $20 \mathrm{~cm}$. below the surface. The area is interesting because the stones were larger than anywhere else on the site. Two clear stakeholes were recorded in the west section of XIIH and may be the 


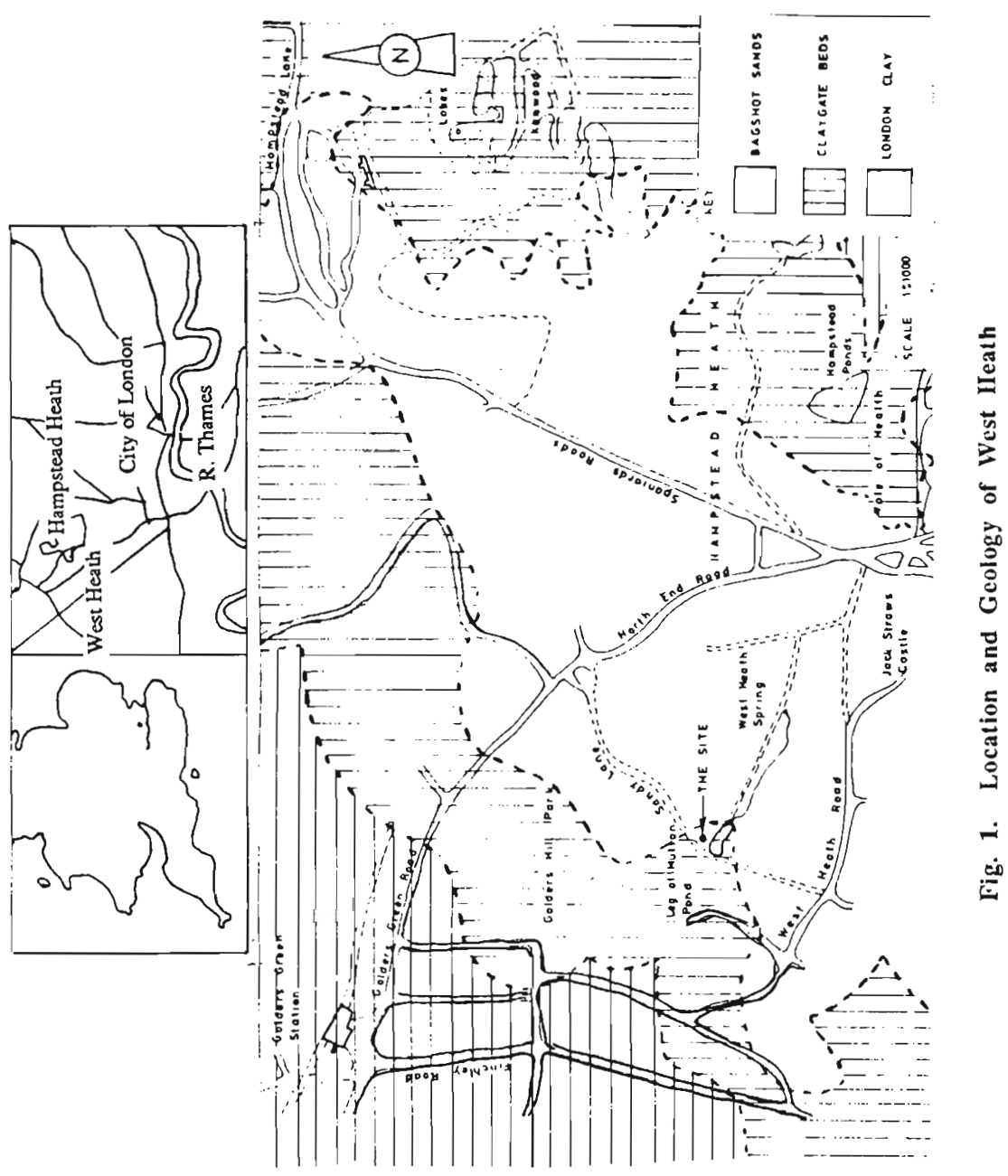




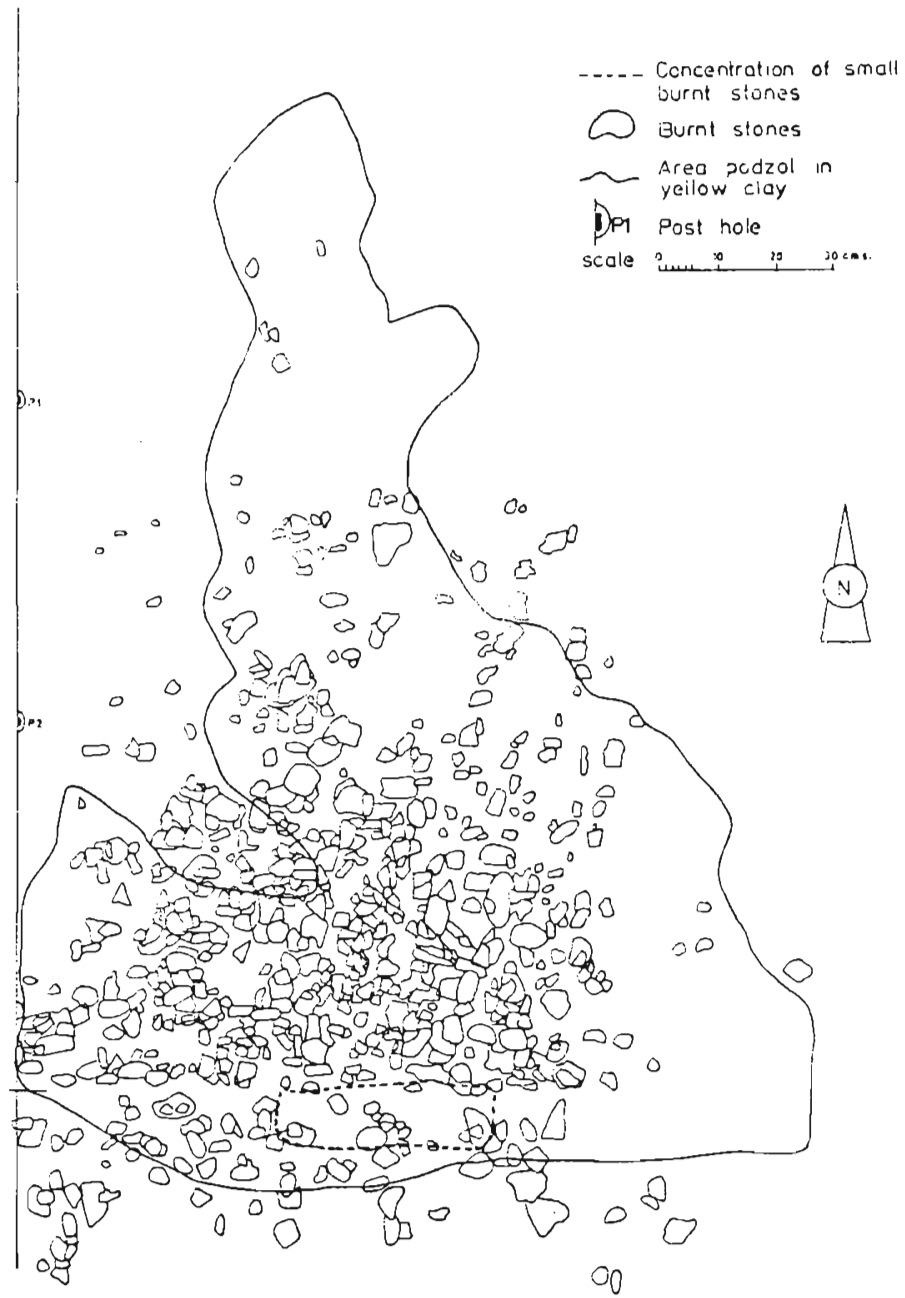

Fig. 3. XII H pit

remains of a wind-break around the fire or of a drying rack - perhaps for drying meat. Adjacent areas have a comparatively low burnt stone count and this trend was confirmed by the phase 2 excavation. Thus it would seem arguable that we have evidence of an activity being carried out away from the principal fire area and using a different technique from that used elsewhere. 
The main knapping areas were well away from this fire area, too, and this suggests that more space was needed for the activity and/or it was considered desirable for it to proceed away from the general living area. Skin preparation, including the scraping away of fat and/or the production of smoke to cure and colour as described by Binford $(1967,6)$, is a possibility

\section{Results of Phase 2}

Results are being collated and the relationship between the burnt stone and the podzol formation remains problematical. Fires on different levels, as shown by the fluctuations in the stone counts, suggest long term use of the site. A concentration of large stones, $6 \mathrm{~m}$ to the East of that found in XIIH, has been identified. It is adjacent to the pit from which a piece of struck flint was taken for the T.L. test which gave the date of $9625 \pm 900$ B.P.

\section{Acknowledgements}

The following are gratefully thanked and acknowledged: Dr. Desmond Collins and Daphne Home-Lorimer for access to material and trench charts. Margaret Maher for access to material, charts and details of struck flint distributions. The Central Research Fund whose grant enabled the thin-sectioning of geological specimens to be carried out. Johnson Matthey Chemicals Lt. for undertaking heat tests free of charge. Finally, all members of the Hendon and District Archaeological Society whose faithful recording of "the burnt" made the investigation possible.

\section{References}

Bessy, G. 1950. The Investigation of Building Fires. London: H.M.S.O. National Building Studies No. 4.

Binford, L. 1964. Smudge pits and hide smoking, the use of analogy in archaeological reasoning. American Antiquity, 32 (1):1-12.

Bromehead, C. 1925. The Geology of North London. Memoirs of the Geological Survey of England and Wales. London.

Crabtree, D.E. \& Butler, R. 1964. Notes on the experiments in flint knapping: heat treatment of silica material. Tebiwa, 7 (1):1-6

Inizan, M.L., Roche, H. \& Tixier, J. 1976-77. Aventage d'un traitement thermique pour la taille des roches siliceuses. Quaternaria, XIX:1-18.

Maher, M. 1983. Knapping areas at the mesolithic site, West Heath, Hampstead. Unpublished B.A. Dissertation, Institute of Archaeology, University College London.

Melcher, C. L. \& Zimmerman, C.W. 1977. Thermoluminescent determination of prehistoric heat treatment of chert artefacts. Science, 197:1359.

Price, T.D., Chappell, S. \& Ives, D.J. 1982. Thermal alteration in mesolithic assemblages. Proceedings of the Prehistoric Society, 48:467.

Weymouth, J. \& Williamson, W. 1951. Some physical properties of raw and calcined flint. Mineralogical Magazine, 29:573. 